\section{Undernutrition and Early Embryonic Mortality in Merino Ewes}

UNTIL recently there was little evidence that the plane of nutrition in early pregnancy could affect ovine foetal growth or survival ${ }^{1-3}$. In the past year or so, however, it has been shown that maternal undernutrition during the first 90 days of gestation may influence foetal weight at 90 days $^{4}$ and possibly embryo survival ${ }^{5}$.

In a recent investigation in this Department, shortterm, severe nutritional stresses during the first 20 days of pregnancy have resulted in increased embryonic mortality. Groups of mature Merino ewes (mean body-weight, $96 \mathrm{lb}$.) were submitted to 7-day periods of sub-maintenance feeding from mating (day 0 ) to day 20 postmating. Numbers of ova shed were recorded by counting corpora lutea at laparotomy, and subsequent embryonic loss or fertilization failure was assessed by return to service, pregnancy test by laparotomy about day 40 , and lambing performance. The imposed stress consisted of 7 days in a bare yard, with a ration of $100 \mathrm{~g} /$ head/day lucerne hay, plus water. A mean body-weight loss of $3 \mathrm{lb}$. per sheep resulted.

Oestrus was synchronized, using progesterone, in 150 Merino ewes, and the ewes were hand-mated to fertile rams at the second post-synchronization oestrus. They were then divided at random on the basis of bodyweight into groups of 30,30 and 90 ewes. One group of 30 received sub-maintenance treatment from day 0 to 7 (Group 1); the second group (2), their control, grazed normally. Ewes in Groups 1 and 2 were laparotomized and their corpora lutea counted on day 12 .

Laparotomy was performed on the remaining 90 ewes on day 6 , and these were then randomized according to body-weight and number of ova shed into three groups of 30 ewes. Group 3 received sub-maintenance treatment from day 6 to 13 and Group 4 from day 13 to 20 ; Group 5 was a control. Except during sub-maintenance treatment, all ewes were paddock-grazed together on adequate pasture. During pregnancy their mean body-weight gain was $22 \mathrm{lb}$.

Following mating, the ewes were run with raddled fertile rams for 7 weeks, after which raddled infertile rams were introduced. Returns to service were recorded daily to day 60 , and thereafter thrice weekly. On day $40( \pm 2)$, ewes which had not returned to service were tested for pregnancy by laparotomy. Just prior to lambing, the groups were separated so that an accurate count of lambs born in each group was obtained.

Table 1 shows the experimental layout and the results in terms of ova shed and their eventual fate. Significantly $(P<0.05)$ less lambs were born in the treatment groups than in the controls.

Table 1. Ovulation, Lambing and Gmbryonic Mortality Data by \begin{tabular}{rcccccc} 
Group & $\begin{array}{c}\text { Treat- } \\
\text { ment }\end{array}$ & $\begin{array}{c}\text { No. of } \\
\text { ewes }\end{array}$ & $\begin{array}{c}\text { No. of } \\
\text { ova }\end{array}$ & $\begin{array}{c}\text { No. of } \\
\text { lambs born }\end{array}$ & $\begin{array}{c}\text { No. } \\
\text { lambs } \\
\text { Per cent }\end{array}$ \\
1 & Day $0-7$ & 29 & 44 & 26 & 18 & $40 \cdot 9$ \\
3 & Day $6-13$ & 30 & 43 & 22 & $21 *$ & $48 \cdot 8$ \\
4 & Day 13-20 & 29 & 41 & 20 & 21 & $51 \cdot 2$ \\
Sub total & 88 & 128 & 68 & $60 \dagger$ & $46 \cdot 9$ \\
2 & Control & 30 & 43 & 31 & 12 & $27 \cdot 9$ \\
5 Control & 30 & 44 & 29 & 15 & $34 \cdot 1$ \\
Sub total & 60 & 87 & 60 & 27 & $31 \cdot 0$ \\
\multicolumn{2}{l}{ Total } & 148 & 215 & 128 & 87 & $40 \cdot 5$
\end{tabular}

* Groups 3 and 4 versus group 5. $P<0.10>0.05$

$\uparrow$ Trcatments versus controls. $P<0.05$.

There was a high level of homogeneity within treatment groups and within controls, but differences between individual treatment and control groups did not reach significance.

Further analysis of the data showed that the loss of potential lambs was significantly higher $(P<0.01)$ among ova shed as twins than as singles.

The apparent embryonic deaths in Group I did not result in prolonged oestrus cvcles, but in each of Groups
3 and 4, following nutritional stresses during the second and third weeks after mating, respectively, five ewes experienced cycles exceeding 22 days in length. Each of the control groups had one such ewe. This is considered to be strong supporting evidence that embryonic deaths have, in fact, resulted from the treatments.

The effect of early embryonic death on subsequent cycle-lengths is now being subjected to detailed investigation, and further work on the effect of nutritional stress in the pre-implantation period is in progress.

\section{T. N. EDEY}

Department of Livestock Husbandry,

University of New England,

Armidale, New South Wales.

${ }^{1}$ Wallace, L. R., J. Agric. Sci., 38, 93, 243, 367 (1948).

${ }^{2}$ El-Sheikh, A. S., Hulet, C. V., Pope, A. L., and Casida, L. E., J. Anim. Sci., 14, 919 (1955).

${ }^{3}$ Coop, I. E., Proc. Ruakura Fmrs. Conf., 69 (1964).

4 Everitt, G. C., Nature, 201, 1341 (1964).

Bennett, D., Axelsen, A., and Chapman, H. W., Proc. Austral. Soc. Anim. Prod. (in the press).

\section{Human Lymphocytes cultured in Microplates}

LXMPHOCYTES from peripheral blood can be stimulated to undergo blast-like transformation when cultured in vitro ${ }^{1}$. This reaction is revealed by many techniques including direct morphological observations, the appearance of mitotic figures in dividing cells, and specific staining or autoradiography for the various biochemical processes involved in cell division ${ }^{2}$. Although any of these techniques is satisfactory, the percentage of transforming cells in many specific immune reactions is low ${ }^{3}$, making standardization both tedious and difficult. In addition, in culture, a small percentage of lymphocytes undergo blast transformation in unstimulated controls either spontaneously or possibly because of prior sensitiza. tion of the individual to one of the products in the tissueculture medium ${ }^{4}$.

We attempted to avoid some of these difficulties by using microtechniques which enabled us to test an individual's cells against a series of antigens on successive days and to have each determination matched by at least one control. So far we have only used the method of counting cells in metaphase (mitotic index) to standardize our observations. We shall report initially promising results as well as details of the method of growth of lymphocytes in microplates and some data of individual variation in responses to phytohaemagglutinin (PHA).

A disposable glass $10-\mathrm{ml}$. syringe was pre-wetted with heparin, leaving about $0 \cdot 2 \mathrm{ml}$. in the syringe. Exactly $10 \mathrm{ml}$. of venous blood was drawn and the syringe was placed upright at room temperature to allow the red cells to sediment. When red cells had settled, leaving $4 \mathrm{ml}$. of plasma above the cell pack ( $30 \mathrm{~min}-3 \mathrm{~h}$ depending partially on room temperature), the needle was bent into a U-shape and by gentle pressure on the plunger the plasma was ejected into a collecting tube. This plasma contained some red cells, and the white cell counts on numerous occasions ranged from 6 million to 10 million cells per cubic $\mathrm{ml}$. The cells were agitated to assure equal distribution in the plasma and one drop of the plasma-cell suspension was placed in each well of plastic disposable U-shaped microplates (Cooke Engineering Co. 220-24). Initially, we used micropipettes, but found that disposable Pasteur pipettes were sufficiently accurate for our needs. To the drop of plasma-cell suspension we added three drops of tissue culture medium, either alone as a stock solution or containing phytohaemagglutinin (PHA) or a known antigenic product. Our basic medium was Modium 199 with inactivated foetal calf serum, and penicillin, streptomyein, acromicin and myeostatin. $I_{n}$ order to determine the optimum concentration of PHA, old tuberculin (OT), purified protein derivative (PPD) or 